\title{
Immunocytochemical analysis of human synovial lining cells: phenotypic relation to other marrow derived cells
}

\author{
N A Athanasou, J Quinn
}

\begin{abstract}
The antigenic phenotype of human synovial lining cells in normal and hyperplastic synovium intima was determined with a panel of monoclonal antibodies directed against a large number of well defined myeloid (macrophage/granulocyte associated) antigens. Synovial lining cells express numerous macrophage associated antigens, including CD11b (CR3), CD13, CD14, CD16 (FcRIII), CD18, CD32 (FcRII), CD45 (leucocyte common antigen), CD54 (ICAM-1), CD64 (FcRI), $\mathrm{CD68}$, and $\mathrm{CD71}$ (transferrin receptor). Few synovial lining cells expressed CD11a (LFA-1) and CD11c (p150,95). Subintimal macrophages expressed all the macrophage associated antigens which were present on synovial lining cells and, in addition, expressed CD15a, CD25 (interleukin-2 receptor), CD34, and CD35 (C3b receptor), none of which was present on synovial lining cells. Synovial lining cell expression of a wide range of macrophage antigens argues in favour of their marrow origin and membership of the mononuclear phagocyte system.
\end{abstract}

The synovial membrane contains a distinctive intimal lining, one to two cells thick, composed of specialised synovial lining cells. ${ }^{1}$ A macrophage-like type A synovial lining cell has been described $^{12}$ by means of ultrastructural, ${ }^{2-6}$ histochemical, ${ }^{7}$ functional, ${ }^{1}$ and immuno$\operatorname{logical}^{8-12}$ investigations. Experiments with mouse radiation chimeras ${ }^{13}{ }^{14}$ and the immunohistochemical demonstration of leucocyte common antigen ${ }^{12}$ and monocyte/macrophage markers ${ }^{8-12}$ on synovial lining cells have shown that some of these cells originate in bone marrow. These cells are known to be actively phagocytic ${ }^{15-18}$ and, together with subintimal macrophages, form what has been described as the articular territory of the reticuloendothelial system. ${ }^{16}$ In conditions such as rheumatoid arthritis and osteoarthritis, where there is synovial lining cell hyperplasia, increased numbers of cells with macrophage-like features are present in the synovial intima. ${ }^{12-14} 19$

Although type A cells in the synovial lining are considered part of the mononuclear phagocyte system, their precise lineage and developmental pathway is unknown. It is not certain whether type A synovial lining cells are simply direct products of the monocyte/macrophage lineage, differentiating further in situ to form specialised synovial lining cells, or whether, as has been suggested for other tissue specific members of the mononuclear phagocyte system, ${ }^{20} 21$ synovial lining cell specific progenitors are produced in the marrow by a synovial lining cell lineage that diverges at some early stage from that of monocytes and tissue macrophages.

To investigate the origin and development of synovial lining cells further we sought to define the antigenic phenotype of human synovial lining cells and subintimal macrophages in the synovial membrane. We used a large number of monoclonal antibodies directed against defined myeloid (granulocyte/macrophage associated) antigens for the immunohistochemical staining of human synovial lining cells and subintimal macrophages in the synovial membrane. The pattern of antigen expression by these cells not only has implications for synovial lining cell origin and development but also for function and interaction of these cells with other inflammatory cells. It also provides a means whereby cells of synovial origin can be identified immunohistochemically.

\section{Materials and methods}

Synovial membrane was obtained during open surgery for joint replacement of osteoarthritic hip joints (four cases, age range 55-70, two male, two female). Synovium associated with osteoarthritis was chosen as it has previously been shown that in this condition cells derived from marrow are present in the synovial intima of normal or increased thickness. ${ }^{12}$

The synovium was received unfixed and snap frozen in liquid nitrogen. Cryostat sections (5 $\mu \mathrm{m})$ were cut, placed on gelatin coated glass slides, and then fixed in cold acetone. An indirect immunoperoxidase technique was carried out. ${ }^{22}$ Antibodies were in the form of ascites or purified immunoglobulin diluted $1: 100$ and 1:250 in phosphate buffered saline. The monoclonal antibodies were largely derived from the non-lineage and myeloid panels of the IVth international workshop on human leucocyte differentiation antigens. These monoclonal antibodies were grouped into various antigenic clusters, which were determined by the differences in pattern or reactivity against marrow circulating and tissue fixed phagocytes. ${ }^{23}$ Table 1 shows details of these cluster defined (CD) and other antigens. Full details of antibodies are given in reference 23. Positive control consisted of antibody to common HLA-A, B, C determinants (WK/32HK). Negative controls consisted of the addition of phosphate buffered saline alone without primary antibody. The proportion of synovial lining cells in the synovial intima staining for a particular antigen was
Correspondence

Accepted for publication 3 June 1990 
Table 1 Momoclonal antibodies used in this study and their antigen/cell specificity

\begin{tabular}{|c|c|c|c|}
\hline Cluster & Antibodies & $\begin{array}{l}\text { Mol wt } \\
\text { (kilodaltons) }\end{array}$ & Cell specificity (antigens) \\
\hline CDIla & $\begin{array}{l}\text { MH24, 11H6, CR1S-3, 122-2A5, BU17, } \\
\text { BU49 GRT22, M232, 0501, MEM25, } \\
\text { MEM30, MEM83, MEM95, 25.3.1, IL11, } \\
\text { 459, CLB54, YFC51.1, YTH81.5, YFC118.3, } \\
\text { 1524, 2F12, F110.22, TMD3-1, ITM3-2, } \\
\text { CC51D7. VIPIIIB1, GRF1. HII1) M10 }\end{array}$ & 180 & Many leucocytes (LFA-1) \\
\hline CD1lb & $\begin{array}{l}\text { 44, JML-H11, LPM19C, 14B6.E2, SA4.C5, } \\
\text { MO1, MN41, MJ5/1, TMG6-5, VIM12 }\end{array}$ & 155 & Granulocytes, monocytes; Mac-1 (CR3:C3bi receptor) \\
\hline $\begin{array}{l}\text { CD11c } \\
\text { CD13 }\end{array}$ & $\begin{array}{l}\text { 3.9, B-LY6, F9083, S-HCL3, L29 } \\
\text { MoU48, 3D8, WM15, U71, U81, TUK1 }\end{array}$ & $\begin{array}{l}150 \\
180\end{array}$ & $\begin{array}{l}\text { Granulocytes, monocytes (p150,95) } \\
\text { Granulocytes, monocytes, macrophages, bile } \\
\text { canaliculi, connective tissues }\end{array}$ \\
\hline CD14 & $\begin{array}{l}\text { CIB-Mon/1, UCHM1, M-M42, VIM-13, } \\
\text { RPA-M1, GRS1, 90.3, 10G3.3, LOM-01, } \\
\text { JML-H14 }\end{array}$ & 55 & Monocytes, macrophages, dendritic reticulum cells \\
\hline CD15a & VIMD5, 6F3, bra4F1, L16, JML-H15 & $50-180$ & $\begin{array}{l}\text { Granulocytes, some monocytes, epithelium, } \\
\text { Reed-Sternberg cells (hapten X) }\end{array}$ \\
\hline $\begin{array}{l}\text { CD16 } \\
\text { CD18 }\end{array}$ & $\begin{array}{l}\text { VEP13, My23 } \\
\text { MH23 }\end{array}$ & $\begin{array}{l}50-65 \\
95\end{array}$ & $\begin{array}{l}\text { Granulocytes, some monocytes (FcRIII molecule) } \\
\text { ( } \beta \text { Chain of LFA-Macl-p150,95 family). } \\
\text { Many leucocytes }\end{array}$ \\
\hline CD25 & TAC & 55 & $\begin{array}{l}\text { Activated lymphocytes, macrophages } \\
\text { (interleukin-2 receptor) }\end{array}$ \\
\hline CD31 & L33, SG-134, 8/3, TM2 & 140 & $\begin{array}{l}\text { Granulocytes, monocytes, macrophages, platelets, } \\
\text { endothelium }\end{array}$ \\
\hline CD32 & MAbIV.3, 2E1, CIKM3 & 40 & $\begin{array}{l}\text { Granulocytes, B cells, monocytes, macrophages, } \\
\text { platelets (FcRII receptor for IgG) }\end{array}$ \\
\hline $\begin{array}{l}\text { CD33 } \\
\text { CD34 }\end{array}$ & $\begin{array}{l}\text { My9, H153, L4F3 } \\
\text { My10, B1-3C5 }\end{array}$ & $\begin{array}{r}67 \\
115\end{array}$ & $\begin{array}{l}\text { Early myeloid progenitors, macrophages, AML } \\
\text { Some myeloids cells, myeloid progenitors, } \\
\text { endothelium }\end{array}$ \\
\hline CD35 & E11, T05, JML-H13 & $220-250$ & $\begin{array}{l}\text { Dendritic reticulum cells, red blood cells, } \\
\text { granulocytes, glomeruli, monocytes (CR1:C3b } \\
\text { receptor) }\end{array}$ \\
\hline $\begin{array}{l}\text { CD36 } \\
\text { CD37 } \\
\text { CD39 }\end{array}$ & $\begin{array}{l}\text { 5F1 } \\
\text { HD28 } \\
\text { G28-10 }\end{array}$ & 85 & $\begin{array}{l}\text { Monocytes, platelets } \\
\text { B cells, weakly on macrophages, T cells } \\
\text { B cells, macrophages, endothelium, other cells }\end{array}$ \\
\hline CD45 & $\begin{array}{l}\text { 124-2H12B, 135-4C5, 135-4H9, U87, AA44, } \\
\text { AB103, AA14, X16, GRT4, GRT3, GRT2, } \\
\text { H130, BRA55, TL-1, F10-89-4, BMAC-1, } \\
\text { BMAC-2, BMAC-3, IOR-L3, RP1/10, 03/9, } \\
\text { YTH24.5, YTH54.12, 80.2, 71.5, GB3, } \\
\text { T2/48, TU116, T29/33, 562/10D3 }\end{array}$ & 200 & Leucocytes (leucocyte common antigen) \\
\hline $\begin{array}{l}\text { CD54 } \\
\text { CD64 }\end{array}$ & $\begin{array}{l}\text { 8F5, Myl3, RR1/1.11, LB-2 } \\
24 \text { (Hogg) }\end{array}$ & 85 & $\begin{array}{l}\text { (ICAM-1) } \\
\text { FCRI receptor }\end{array}$ \\
\hline CD68 & EBM/11, Y-1/82a, KiM6, Y2/131, KiM7 & 110 & $\begin{array}{l}\text { Pan-mononuclear phagocyte system, renal } \\
\text { tubular epithelium }\end{array}$ \\
\hline CD71 & $\begin{array}{l}\text { DF1513, VIP-1 } \\
\text { CIIII.47, CR } 3 / 43 \text { (Mason) } \\
\text { WK } / 32 \mathrm{HK}\end{array}$ & 90 & $\begin{array}{l}\text { Transferrin receptor } \\
\text { Class II MHC (HLA-DR) } \\
\text { Class I MHC (positive control) }\end{array}$ \\
\hline
\end{tabular}

All the above antibodies, unless indicated, were derived from the 4th international workshop on human leucocyte differentiation antigens. ${ }^{18}$

determined after counting 500 cells in five high power fields. ${ }^{24}$ Results are expressed as a percentage of CD14 and CD68 (monocyte/ macrophage associated antigen) stained cells.

\section{Results}

The four examples of osteoarthritic synovium showed oedema of the subintima and had a synovial intima of normal (one to two cells) or increased (three or more cells) thickness. Scattered subintimal macrophages were also noted in the synovial membrane.

SYNOVIAL LINING CELL ANTIGENIC PHENOTYPE Table 2 shows the antigenic phenotype of synovial lining cells in the synovial membrane. Synovial lining cells expressed leucocyte common antigen (CD45); this was present on only isolated cells $(25 \%)$ in synovial intima of normal thickness but was present on almost all ( $>95 \%$ ) synovial lining cells in portions of hyperplastic synovial intima. A similar percentage of cells also showed strong membrane staining for myeloid antigens, CD11b (CR3), CD13, CD14, CD16 (FcRIII), CD18 ( $\beta$ chain of LFA family), CD31, CD32 (FcRII), CD33, CD36, CD37, CD39, CD54 (ICAM-1), CD64 (FcRI), and CD71 (transferrin receptor) (figure). There was also strong cytoplasmic staining for CD68 (tissue-macrophage associated antigen) and strong membrane staining for HLA-DR on almost all (>90\%) synovial lining cells. Few ( $<5 \%$ compared with CD14 and CD68 staining)

Table 2 Expression of myeloid antigens by synovial lining cells and subintimal macrophages in the synovial membrane

\begin{tabular}{|c|c|c|}
\hline$C D$ antigen & $\begin{array}{l}\text { Symovial } \\
\text { lining cells }\end{array}$ & $\begin{array}{l}\text { Subintimal } \\
\text { macrophages }\end{array}$ \\
\hline CDIla & $+^{*}$ & + \\
\hline CDIlb & t+ & $+t$ \\
\hline CDilc & $+^{*}$ & \\
\hline CD13 & ++ & ++ \\
\hline CD14 & ++ & ++ \\
\hline CD15a & - & + \\
\hline CD16 & + & \\
\hline CD18 & ++ & ++ \\
\hline CD25 & - & + \\
\hline CD31 & ++ & ++ \\
\hline CD32 & + & + \\
\hline CD33 & + & + \\
\hline CD34 & - & + \\
\hline CD35 & - & + \\
\hline CD37 & + & + \\
\hline CD39 & + & + \\
\hline CD45 & ++ & ++ \\
\hline & ++ & \\
\hline CD64 & & \\
\hline CD68 & ++ & $\dot{+}+$ \\
\hline CD71 & ++ & ++ \\
\hline MHC class (HLA DR) & & \\
\hline Control HLA class I & $\stackrel{+}{-}$ & $\stackrel{+}{-}$ \\
\hline
\end{tabular}

$-=$ No reaction; $+=$ weak reaction; $++=$ strong reaction. $* 5 \%$ cells stained (see 'Results'). 
synovial lining cells in both normal and hyperplastic areas of the synovial membrane reacted with antibodies directed against CD11c (p150, 95) and CD1 la (LFA-1) (figure D). No reaction for CD15a (hapten X), CD25 (interleukin-2 receptor), $\mathrm{CD} 34, \mathrm{CD} 35$ (C3b receptor), or CD43 was seen in synovial lining cells.

All the above antigens exposed by synovial lining cells were also present on monocytes or macrophages according to the workshop study. ${ }^{23}$ Subintimal mononuclear cells in the synovial membrane also reacted with those monoclonal antibodies which stained synovial lining cells. No specific antibody reacting with synovial lining cells was identified. There was intense staining for HLA-DR in the osteoarthritic synovial lining. Serial sectioning showed that many of these HLA-DR positive cells did not contain macrophage markers and leucocyte common antigen, suggesting that they were not type A cells derived from marrow.

SUBINTIMAL MACROPHAGE ANTIGENIC PHENOTYPE Subintimal macrophages were identified morphologically and by reaction with workshop antimacrophage antibodies directed against CD14 and CD68. These cells reacted with all the antibodies which stained synovial lining cells; the reaction on subintimal macrophages was also of similar pattern and intensity to that on synovial lining cells. Subintimal macrophages also reacted with antibodies directed against CD1la and CD11c, with many cells (>50\% compared with CD68 and CD14 staining) showing a strong membrane reaction. In addition, a similar proportion of subintimal macrophages showed variable $(10-40 \%)$ but largely weak expression of CD15a, CD25, CD34, and CD35. There was also intense HLADR positivity of subintimal macrophages and other mononuclear spindle and round cells in the subintimal stroma as well as some endothelial cells lining blood vessels. Endothelial cells were also strongly stained by antibodies to CD32, CD34, CD39, and CD54.

\section{Discussion}

This study has shown that synovial lining cells in both normal and hyperplastic areas of the synovial lining express numerous leucocyte and monocyte/macrophage associated antigens. This includes expression of CD45 (leucocyte common antigen), CD1la,b,c, and CD18 of the lymphocyte function associated antigen family, CD13, CD14, CD16 (FcRIII receptor), CD31, CD32 (FcRII receptor), CD33, CD37, CD39, CD54 (ICAM-1), CD64 (FcRI receptor), CD68, CD71 (transferrin receptor), and HLADR antigen. These antigens are also present on tissue (including subintimal) macrophages and in
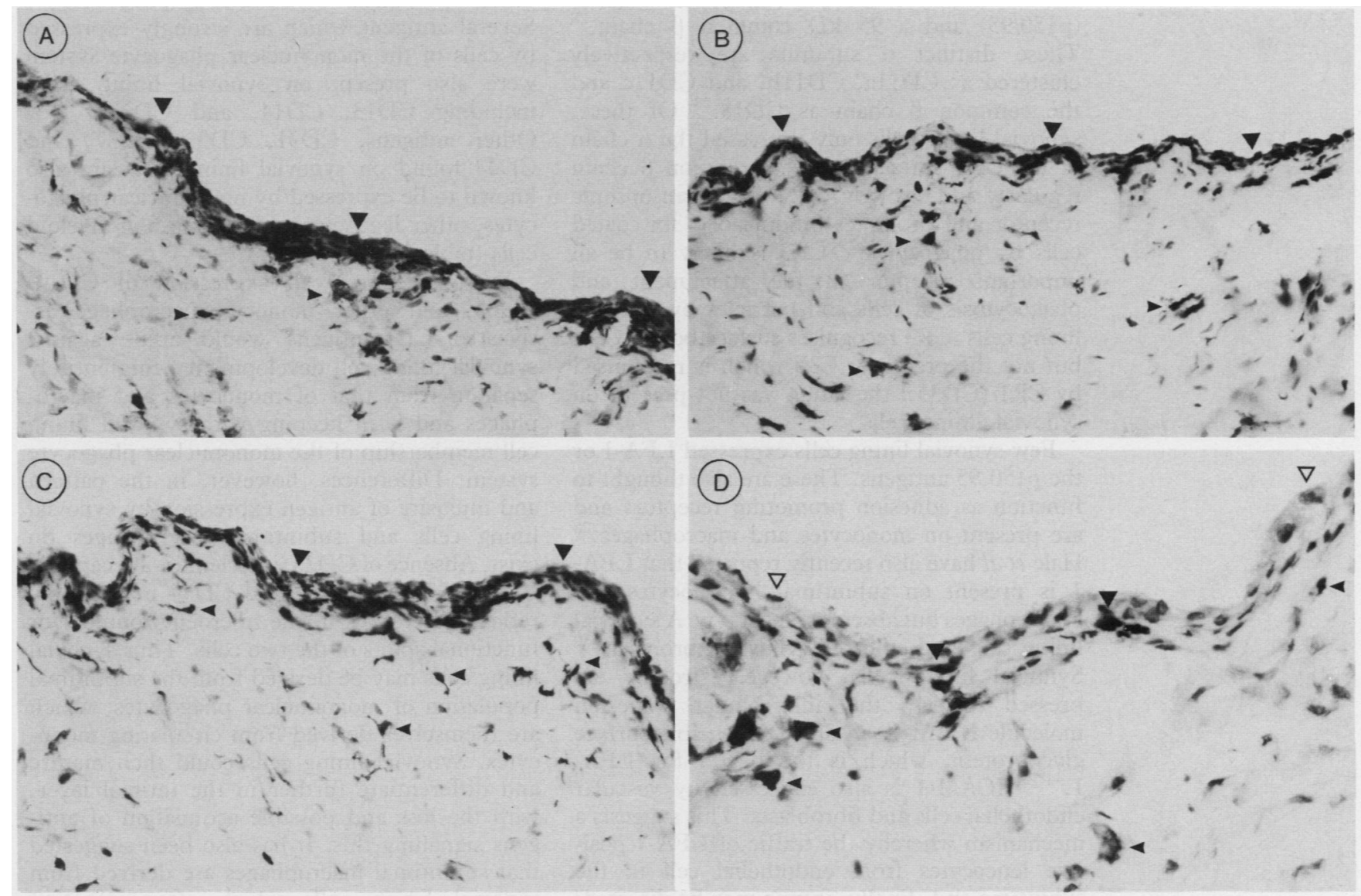

Indirect immunoperoxidase staining of synovial membrane showing positive reaction of synovial lining cells in synovial intima (large arrows) and subintimal macrophages (small arrows) for $(A) C D 14$ (monocyte/macrophage associated antigen) with monoclonal antibody CIB-Mon1; $(B) C D 68$ (macrophage associated antigen) with monoclonal antibody EBM/11; C C CD $32(F c R I I$ receptor) with monoclonal antibody $2 E 1 ;(D) C D I 1 c(p 150,95)$ with monoclonal antibody L29. Here, in contrast with the above, there are few positive synovial lining cells in the intima and few positive subintimal macrophages. The open arrow indicates unstained synovial lining cells. 
some cases, blood monocytes and other marrow derived cells. The synovial lining cell antigenic phenotype was distinguished from that of tissue macrophages by the absence of several antigens, including CD15a, CD25, CD34, and CD35 and weak expression of CD1la and CD1lc.

Expression of common surface and cytoplasmic antigens is hardly surprising as synovial lining cells and macrophages have similar origins, structures, cytochemistry, and functions. ${ }^{1}$ Leucocyte common antigen (CD45) is expressed on the cell membrane of all cells derived from the haemopoietic stem cell and is present on other cells of the mononuclear phagocyte system. ${ }^{25} 26$ This indicates that there are cells of bone marrow origin in the synovial lining and that most cells which contribute to hyperplasia of the synovial intima also originate in the bone marrow. The finding of distinct groups of synovial lining cells with and without leucocyte common antigen in the synovial lining of normal thickness argues in favour of the existence of the two distinct, rather than a single, cell type, expressing either type A or type B morphology depending on its microenvironment or functional state. ${ }^{27}$

Synovial lining cells and subintimal macrophages variably expressed antigens of the lymphocyte function associated antigen family. 'This is a family of cell surface molecules that are important in intercellular and cell matrix adhesion reactions. These molecules consist of three non-covalently associated heterodimers with distinct $\alpha$ chains of molecular weight $180 \mathrm{kD}$ (LFA-1), $155 \mathrm{kD}$ (CR3), and $150 \mathrm{kD}$ (pl50/95) and a $95 \mathrm{kD}$ common $\beta$ chain. ${ }^{28}$ These distinct $\alpha$ subunits are respectively clustered as CDIla, CDIlb, and CDIlc and the common $\beta$ chain as $\mathrm{CD} 18 .^{23}$ Of these, synovial lining cells only expressed the $\alpha$ chain of the CR3 antigen and the common $\beta$ chain regularly and strongly. CR3 acts as an opsonic receptor and promotes binding of $\mathrm{C} 3 \mathrm{bi}$ coated cells by phagocytes. ${ }^{29}$ CR3 is likely to be an important receptor in the attachment and phagocytosis of cells and particles by synovial lining cells. CR3 recognises surface bound $\mathrm{C} 3 \mathrm{bi}$ but not the precursor $\mathrm{C} 3 \mathrm{~b}$ which is recognised by CR1 (CD35); the latter was not present on synovial lining cells.

Few synovial lining cells expressed LFA-1 or the p150,95 antigens. These are also thought to function as adhesion promoting receptors and are present on monocytes and macrophages. ${ }^{28}$ Hale $e t$ al have also recently reported that LFA1 is present on subintimal lymphocytes and macrophages but absent on most type A synovial lining cells and cultured synovial fibroblasts. ${ }^{30}$ Synovial lining cells, however, strongly expressed CD54, the intercellular adhesion molecule ICAM-1, an $88 \mathrm{kD}$ inducible surface glycoprotein, which is the ligand for LFA1. ${ }^{31} 32$ ICAM-1 is also expressed by vascular endothelial cells and fibroblasts. This suggests a mechanism whereby the traffic of LFA-1 positive leucocytes from endothelial cell to the subintima and, finally, intima may be directed. Such reactions may be important in the production and maintenance of chronic synovial inflammation and exudation of inflammatory cells into the synovial fluid. Direct interaction between leucocytes and synovial lining cells is also possible through an LFA-1/ICAM-1 receptor ligand pairing, a mechanism whereby these inflammatory cells may modulate synovial lining cell function. Allen et al have also recently shown that few synovial lining cells in normal or osteoarthritic synovium express CD11c and that expression of this molecule is increased in rheumatoid synovium. ${ }^{33}$ Similarly, p150,95 may play a part in cellular interactions which are important in initiating and perpetuating synovial inflammation by modulation of inflammatory cell migration in the synovial membrane.

Synovial lining cells also expressed other receptors which are important in phagocytosis and endocytosis, including the three receptors for the Fc portion of immunoglobulin-FcRI (CD64), FcRII (CD32), and FcRIII (CD16). Most synovial lining cells, including those without leucocyte common antigen or macrophage antigens, also showed strong staining for HLA-DR in both normal and hyperplastic synovium. This indicates that these antigens are expressed by both type A (marrow derived) and type B (non-marrow derived) synovial lining cells and is in keeping with several previous studies which have studied HLA-DR positive cell populations in normal and arthritic synovium. ${ }^{9-11}$ 34-38 $^{38}$ Expression of receptors for iron transport is in keeping with the well recognised ability of synovial lining cells to take up blood and haemosiderin pigment and is a feature of other specialised mononuclear phagocytes. ${ }^{39}$ Several antigens which are strongly expressed by cells of the mononuclear phagocyte system were also present on synovial lining cells, including CD13, CD14, and CD68. ${ }^{23} 40-44$ Other antigens, CD 31, CD 33, CD 37, and CD44 found on synovial lining cells are also known to be expressed by mononuclear phagocytes, other leucocytes, and some non-myeloid cells (table 1).

Synovial lining cell expression of CD14, CD68, and other monocyte/macrophage associated $C D$ antigens would argue against synovial lining cell development being entirely separate from that of monocytes and macrophages and is in keeping with synovial lining cell membership of the mononuclear phagocyte system. Differences, however, in the pattern and intensity of antigen expression by synovial lining cells and subintimal macrophages do exist. Absence of CD25 (interleukin-2 receptor), CD35 (C3b receptor), and CD34 may simply reflect differences in the microenvironment or functional status of the two cells. Thus synovial lining cells may be derived from the subintimal population of mononuclear phagocytes, which are themselves derived from circulating monocytes. Synovial lining cells could then mature and differentiate further in the intimal layer, with the loss and possible acquisition of antigens signalling this. It has also been suggested that subintimal macrophages are derived from synovial lining cells which after ingesting material wander down into the subsynovial tissue. ${ }^{16}$ If this is the case, such migration is associated with increased expression of LFA-1, pl50,95 and expression of antigens such as the 
receptor for interleukin-2. One further possibility, which is also suggested by differences in the antigenic phenotype between synovial lining cells and tissue macrophages, is that there is a distinct cell lineage pathway for synovial lining cells as there seems to be for other tissue specific cells of the mononuclear phagocyte system. $^{20} 21$ This synovial lining cell lineage might diverge early from that of monocytes and tissue macrophages. Thus specific synovial lining cell progenitor cells may exist in the marrow and these could produce site specific circulating mononuclear cells which would then home to the synovial intima.

The use of monoclonal antibodies to define the human synovial lining cell antigenic phenotype and distinguish it from that of subintimal and tissue macrophages should facilitate more precise characterisation of cells which are derived from the synovium and used in in vitro culture studies of synovial cell function. It should also permit assessment of the antigenic phenotype of those cells which are present in pathological lesions that are presumed to be of synovial origin-for example, benign synovioma (giant cell tumour of tendon sheath). ${ }^{45}$ Finally, knowledge of the antigenic phenotype of synovial lining cells and subintimal macrophages is likely to show that different forms of arthritis are characterised by different patterns of antigen expression. This has already been noted for HLA-DR ${ }^{34-36}$ and lymphocyte function associated antigen ${ }^{30}$ expression in rheumatoid synovium.

We thank Miss $\mathrm{L}$ Watts for preparing the manuscript. NAA is an ARC fellow in osteoarticular pathology.

1 Henderson B, Pettipher E R. The synovial lining cell: biology and pathobiology. Semin Arthritis Rheum 1985; 15: 1-32.

and pathobiology. Semin Arthritis Rheum 1985; 15: 1-32. scopy of the human synovial membrane. F Cell Biol 1962; 14: $207-20$

3 Ghadially F N, Roy S. Ultrastructure of rabbit synovial membrane. Ann Rheum Dis 1966; 25: 318-26.

4 Ghadially F N. Fine structure of synovial joints. London: Butterworth, 1983.

5 Graabek P M. Ultrastructural evidence for two distinct type of synoviocytes in rat synovial membrane. F Ultrastruct Res 1982; 78: 321-39.

6 Graabek P M. Characteristics of the two types of synoviocytes in rat synovial membrane: an ultrastructural study. $L a b$ Invest 1984; 50: 690-702.

7 Henderson $B$. The contribution made by cytochemistry to the study of the metabolism of the normal and rheumatoid study of the metabolism of the normal and rheumatoid s2-4.

8 Theofilopoulos A N, Carson D A, Tavassoli M, et al. Evidence for the presence of receptors for $\mathrm{C} 3$ and IgG Fc on human synovial cells. Arthritis Rheum 1980; 23: 1-9.

9 Burmester G R, Dimitriu-Bona A, Waters S J, Winchester $R$ J. Identification of three major synovial lining cell populations by monoclonal antibodies directed to Ia antigens and antigens associated with monocytes/macrophages and fibroblasts. Scand F Immunol 1983; 17: 69-82.

10 Hogg N, Palmer D G, Revell P A. Mononuclear phagocytes of normal and rheumatoid synovial membrane identified by monoclonal antibodies. Immunology 1985; 56: 673-81.

11 Palmer D G, Selvendron Y, Allen C, Revell P A, Hogg N. Features of synovial membrane identified with monoclona Features of synovial membrane identified with mo

12 Athanasou N A, Quinn J, Heryet A, Puddle B, Woods C G, McGee J O'D. The immunohistology of synovial lining cells in normal and inflamed synovium. $\mathcal{F}$ Pathol 1988; 155 : $133-42$.

13 Edwards J C W, Willoughby D A. Demonstration of bone marrow derived cells in synovial lining by means of gian intracellular granules as genetic markers. Ann Rheum $D$ is 1982; 41: 177-82.

14 Edwards J C W. The origin of type A synovial lining cells Immunobiology 1982; 161: 227-31.

15 Adams W S. Fine structure of synovial membrane: phagocytosis of colloidal carbon from the ioint cavity. Lab Invest 1966; 15: 680-91.
16 Ghadially F N. The articular territory of the reticuloendothelial system. Ultrastruct Pathol 1980; 1: 249-64.

17 Ball J, Chapman J A, Muirden K D. The uptake of iron in rabbit synovial tissue following the intraarticular injection of iron dextran: a light and electron microscopic study. 7 Cell Biol 1964; 22: 351-64.

18 Cochrane W, Davies D U, Palfrey A J. Absorptive functions of the synovial membrane. Ann Rheum Dis 1965; 24: 2-15. 19 Henderson B, Revell P A, Edwards J C W. Synovial lining cell hyperplasia in rheumatoid arthritis: dogma and fact. Ann Rheum Dis 1988; 47: 348-9.

20 Dougherty G J, McBride W H. Macrophage heterogeneity f Clin Lab Immunol 1984; 14: 1-11.

21 Mundy G R, Roodman G D. Osteoclast ontogeny and function. In: Peck W A, ed. Bone and mineral research. Amsterdam: Elsevier, 1987: 209-79.

22 Gatter K C, Falini B, Mason D Y. The use of monoclonal antibodies in histopathological diagnosis. In: Anthony P P, MacSween R N M, eds. Recent advances in histopathology, No 12. Edinburgh: Churchill Livingstone, 1984: 35-67.

23 Knapp W, Doerken K, Gilks W R, et al, eds. Leucocyte typing IV. Oxford: Oxford University Press, 1989.

24 Revell P A, Mayston V J. Histopathology of the synovial membrane of peripheral joints in ankylosing spondylitis. Ann Rheum Dis 1982; 41: 579-86.

25 Kurtin P J, Pinkus G S. Leukocyte common antigen-a diagnostic discriminant between hematopoietic and nonhematopoietic neoplasms in paraffin sections using monoclonal antibodies: correlation with immunologic studies and ultrastructural localization. Hum Pathol 1985; 16: 353-65.

26 Cobbold S, Hale G, Waldmann $H$. Non-lineage, LFA-1 family and leucocyte common antigens: new and previously defined clusters. In: McMichael A, et al, eds. Leucocyte typing III. Oxford: Oxford University Press, 1987: $788-803$.

27 Fell H B. Synoviocytes. F Clin Pathol [Suppl] 1978: 14-24.

8 Sanchez Madrid F, Nagy J A, Robbins E, Simon P, Springer T A. A human leukocyte differentiation antigen family with distinct $\alpha$-subunits and a common $\beta$-subunit. $\mathcal{f}$ Exp Med 1983; 158: 1785-803.

29 Wright S D, Detmers P A. Adhesion promoting receptors on phagocytes. F Cell Sci Suppl 1988; 9: 99-120.

30 Hale L P, Martin M E, McCollum D E, et al. Immunohistologic analysis of the distribution of cell adhesion molecules within the inflammatory synovial microenvironment. Arthritis Rheum 1989; 32: 22-30.

31 Rothlein R, Dustin M L, Maerlin S D, Springer T A. A human intercellular adhesion molecule (ICAM-1) distinct from LFA-1. F I mmunol 1986; 137: 1270-4.

32 from LFA-1. F Immunol 1986; 137: 1270-4. Springer T A. Primary structure of ICAM-1 demonstrates interaction between members of the immunoglobulin and integrin supergene family. Cell 1988; 52: $925-33$.

33 Allen C A, Highton J, Palmer D G. Increased expression of p150,95 and CR3 leucocyte adhesion molecules by mononuclear phagocytes in rheumatoid synovial membranes: comparison with osteoarthritis and normal synovial membranes. Arthritis Rheum 1989; 32: 947-54.

34 Klareskog L, Forsum U, Malmnas Tjernlund U, Kabelitz D, Wigner A. Appearance of HLA-DR reactive cells in normal and rheumatoid synovial tissue. Scand F Immunol 1981; 14: and rhe $183-92$.

35 Poulter L W, Duke O, Hobbs S, Janossy G, Panayi G Histochemical discrimination of HLA-DR positive cell populations in the normal and arthritic synovial lining. Clin populations in the normal and a
Exp Immunol 1982; 48: 381-8.

36 Duke O, Panayi G S, Poulter L W. An immunohistological analysis of lymphocyte subpopulations and their micro environment in the synovial membranes of patients with rheumatoid arthritis using monoclonal antibodies. Clin Exp Immunol 1982; 49: 22-30.

37 Palmer D G, Hogg N, Revell P A. Lymphocytes, polymorphonuclear leukocytes, macrophages and platelets in synovium involved by rheumatoid arthritis. A study with monoclonal antibodies. Pathology 1986; 18: 431-7.

38 Shiozawa S, Shiozawa K, Fujita T. Presence of HLA-DR antigens on synovial type $A$ and $B$ cells: an immunoelectron microscope study in rheumatoid arthritis, osteoarthritis and normal traumatic joints. Immunology 1983; 50: 587-94.

39 Gatter K C, Brown G, Trowbridge I S, Woolsten R E, Mason D Y. Transferrin receptors in human tissues: their distribution and possible clinical relevance. $\mathcal{f}$ Clin Pathol 1983; 36: $539-45$.

40 Hogg N, Horton M A. Myeloid antigens: new and previously defined clusters. In: McMichael A et al, eds. Leucocyte typing III. Oxford: Oxford University Press, 1987: 576-602.

41 Look A T, Ashmon R A, Shapiro L H, Peper S C. The human myeloid plasma membrane glycoprotein $\mathrm{CD} 13$

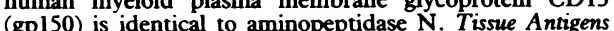
1989; 33: 228 .

42 Parwaresch $M R_{\text {, Radzun } H} J$, Kreipe H, Hansmann M-L, Barth J. Monocyte-macrophage reactive monoclonal antiBarth J. Monocyte-macrophage reactive monoclonal anti-

43 Kelly P M A, Bliss E, Morton J A, Burns J, MçGee J O'D. Monoclonal antibody EBM/11: high cellular specificity for human macrophages. $\mathcal{J}$ Clin Pathol 1988; 41: $510-5$

44 Davey F R, Cordell J L, Erber W N, Pulford K A, Gatter K C, Mason D Y. Monoclonal antibody (Y1/82A) with specificity towards blood monocytes and tissue macrophages. F Clin Pathol 1988; 41: 753-8.

45 Enzinger F M, Weiss S W. Soft tissue tumours. St Louis: Mosby, 1988: 638-58. 